\title{
CARRIER RECOMBINATION PROPERTIES IN LOW-TEMPERATURE-GROWN AND ION-IMPLANTED GaAs *
}

\author{
A. Geižutis ${ }^{\text {a }}$, R. Adomavičius ${ }^{\text {a }}$, A. Urbanowicz ${ }^{\text {a }}$, K. Bertulis ${ }^{\text {a }}$, A. Krotkus ${ }^{\text {a }}$, \\ H.H. Tan ${ }^{\mathrm{b}}$, and C. Jagadish ${ }^{\mathrm{b}}$ \\ a Semiconductor Physics Institute, A. Goštauto 11, LT-01108 Vilnius, Lithuania \\ E-mail: andrejus@opel2.pfi.lt \\ ${ }^{\mathrm{b}}$ Department of Electronic Materials Engineering, Research School of Physical Sciences and Engineering, The Australian \\ National University, Canberra, ACT 0200, Australia
}

Received 29 June 2005

\begin{abstract}
Electron and hole trapping times, electron mobilities were investigated in low-temperature-grown GaAs (LTG GaAs) and GaAs crystals implanted by four different ion species. Optical pump - THz probe and recently developed optical pump mid-IR probe techniques have been used in these experiments. Recombination parameters of the investigated materials were estimated in point of view of possible applications of these materials in $\mathrm{THz}$ radiation devices. It has been concluded that LTG GaAs is preferable material for pulse THz applications because of its shorter electron trapping times and higher electron mobility. However, the hole trapping time in ion-implanted material is shorter than in LTG GaAs, making it a suitable for devices working in cw-mode, e. g. THz photomixers. The shortest carrier trapping times and the largest electron mobility were found for O-implanted GaAs.
\end{abstract}

Keywords: gallium arsenide, ion implantation, carrier trapping time

PACS: $61.72 \mathrm{Vv}, 78.47 .+\mathrm{p}, 78.66 . \mathrm{Fd}$

\section{Introduction}

Generation and detection of $\mathrm{THz}$ radiation using ultrashort laser pulses and photoconductive antennae have been intensively studied during the last decade. The best results were achieved when LTG GaAs grown by molecular beam epitaxy (MBE) was used as a basis for $\mathrm{THz}$ emitters and detectors. This material is characterized by large dark resistivity $\left(10^{7} \Omega \cdot \mathrm{cm}\right)$, reasonably high electron mobility (several hundreds of $\left.\mathrm{cm}^{2} /(\mathrm{V} \cdot \mathrm{s})\right)$, and short carrier lifetime $(<1 \mathrm{ps})$ [1]. As an alternative material to LTG GaAs, GaAs implanted with heavy, high energy ions was proposed $[2,3]$. Because the characteristics of ion-implanted GaAs are strikingly similar to those of LTG GaAs, it could be used as a substrate material for terahertz $(\mathrm{THz})$ photoconductive antennae or other components operating in the $\mathrm{THz}$ frequency range. The use of ion-implanted GaAs has several advantages over LTG GaAs. Ion dosage and hence the properties of the implanted material can be precisely and reproducibly tailored; further-

\footnotetext{
* The report presented at the 36th Lithuanian National Physics Conference, 16-18 June 2005, Vilnius, Lithuania.
}

more, ion implantation offers the feasibility of fine tuning the properties of the semiconductor by varying the appropriate implantation (and annealing) conditions. As yet, there are only few examples of ion-implanted GaAs applications in ultrafast optoelectronic devices, although the feasibility of such devices as semiconductor saturable absorber mirrors (SESAM) [4], photoconductive antennae [5], and surface field THz emitters [6] manufactured from ion-implanted GaAs has been already demonstrated in the literature.

From the application point of view, the most important material parameters are the electron and hole trapping times and the electron mobility. In nonstoichiometric GaAs, where the carrier lifetimes are in the picosecond or sub-picosecond range, the determination of those parameters is rather complicated, therefore a systematic comparison of the materials obtained by different technologies was not performed until now. In the present work, we made such comparison of LTG GaAs epitaxial layers and GaAs implanted with four different ion species. The electron trapping times and their mobilities in these materials were determined by using optical pump - $\mathrm{THz}$ probe technique, whereas 
the hole trapping times were measured by a recently developed optical pump - mid-IR probe method [7].

\section{Samples preparation}

Epitaxial LTG GaAs layers were grown on semiinsulating (100)-oriented GaAs substrates in a SPI solid-state molecular-beam epitaxy system. An $\mathrm{As}_{4} / \mathrm{Ga}$ beam-equivalent pressure ratio equal to 10 and a growth rate of $1.5 \mu \mathrm{m} / \mathrm{h}$ were used for all growth runs. After standard substrate surface cleaning from oxides, a GaAs buffer layer of $500 \mathrm{~nm}$ thickness was grown at $600{ }^{\circ} \mathrm{C}$ substrate temperature. The growth was interrupted and the substrate temperature was lowered to 235-270 ${ }^{\circ} \mathrm{C}$ before the deposition of the LTG layer. The thickness of LTG GaAs layers ranged from 1.5 to $2.5 \mu \mathrm{m}$. The layers were annealed in a rapid thermal annealing (RTA) furnace at temperatures ranging from 450 to $900{ }^{\circ} \mathrm{C}$ for $30 \mathrm{~s}$ in $\mathrm{N}_{2}$ atmosphere and with LTG $\mathrm{GaAs}$ pressed to a sacrificial $\mathrm{GaAs}$ substrate.

For implantation samples, semi-insulating (100) GaAs samples were implanted with four ion species (As, Ga, O, and $\mathrm{Si}$ ). Either $2 \mathrm{MeV}$ arsenic or gallium or $1 \mathrm{MeV}$ silicon or oxygen ion implantation at fluences ranging from $1 \cdot 10^{14}$ to $5 \cdot 10^{16} \mathrm{~cm}^{-2}$ were carried out using the Australian National University (ANU) tandem accelerator. In all cases the implant energies were chosen such that all the ions would have approximately the same projected range. During the implantation, wafers were held nominally at room temperature and tilted $7^{\circ}$ away from the beam axis to reduce channelling effects. After the implantation, the samples were annealed for $20 \mathrm{~min}$ at $600{ }^{\circ} \mathrm{C}$ under an arsine ambient in a metal-organic chemical vapour deposition reactor to prevent excessive loss of arsenic from the surface. Structural, electron transport, and time-resolved photoluminescence measurements on these samples have been performed [3].

\section{Measurements set-up}

Electron dynamics was characterized by employing Ti:sapphire laser pulses (150 fs, $76 \mathrm{MHz}, 800 \mathrm{~nm}$ ). Optical pump $-\mathrm{THz}$ probe technique was used for the electron trapping time measurement and the electron mobility estimation. $300 \mu \mathrm{m}$ pinhole was used to overlap the THz and visible beams on the sample. The spot size of the pump beam was larger than the diameter of the pinhole, so that the THz probe beam was sampling a nearly uniformly photoexcited region. To maximize the transmitted power through the pinhole, the
$\mathrm{THz}$ beam was focused before and collimated after the pinhole by two hemispherical Teflon lenses. THz transients were generated and detected by a pair of photoconductive antennae from LTG GaAs. Optical beams focused to $50 \mu \mathrm{m}$ diameter were used for $\mathrm{THz}$ generation and detection. The average power used for $\mathrm{THz}$ detection was $45 \mathrm{~mW}$. The rest of the laser beam power was distributed between $\mathrm{THz}$ generation and optical excitation arms. The curves presented in Figs. 2, 3, 4, 6,7 were measured with $40 \mathrm{~mW}$ pump power (saturation effects were not observed at such power level in all samples). The proportion of this distribution was changed by means of a $\lambda / 2$ plate and a polarizing beamsplitter. As this set-up was quite sensitive to the photoexcited electrons, a reduction of the $\mathrm{THz}$ power transmitted through the sample due to its absorption by optically excited electrons was easily measurable even if their densities were as low as $10^{16} \mathrm{~cm}^{-3}$.

For the hole trapping time measurement, a novel optical pump - mid-IR probe technique was used [7]. In this technique, the hole trapping time was determined by photoexciting the carriers with $800 \mathrm{~nm}$ wavelength pulses and by probing the intervalence band transitions with $9 \mu \mathrm{m}$ wavelength optical pulses. The latter wavelength corresponds to the resonance transitions between the heavy and light hole valence bands. A clear advantage of this scheme is that the resonant interband hole absorption at this wavelength is stronger than the absorption by free electrons by approximately an order of magnitude [8].

Two-colour pump-and-probe arrangement was based on a femtosecond, tunable wavelength laser system running at a pulse repetition rate of $1 \mathrm{kHz}$. Electronhole pairs are generated in the sample by $800 \mathrm{~nm}$ wavelength 100 fs duration pump pulses generated by the Ti:sapphire laser, and the dynamics of the hole density is monitored by measuring the change in the transmission of $9 \mu \mathrm{m}$ wavelength, $150 \mathrm{fs}$ duration probe pulses. Pump-and-probe beams were focused on the sample surface to the diameters of 1.5 and $0.5 \mathrm{~mm}$, respectively. For generation of the femtosecond pulses continuously tunable in the IR range, a travelling wave optical parametric amplifier (TOPAS, Light Conversion Ltd.) with a difference frequency generator was used. TOPAS was based on type II phase-matched barium borate (BBO) crystal pumped by part $(\sim 65 \%)$ of the fundamental radiation reflected from the beam splitter. To obtain the mid-IR radiation with wavelength of $9 \mu \mathrm{m}$, the wavelength of the signal and idler pulses in TOPAS were set at 1470 and $1755 \mathrm{~nm}$, respectively. The difference frequency was generated in $\mathrm{AgGaS}_{2}$ 


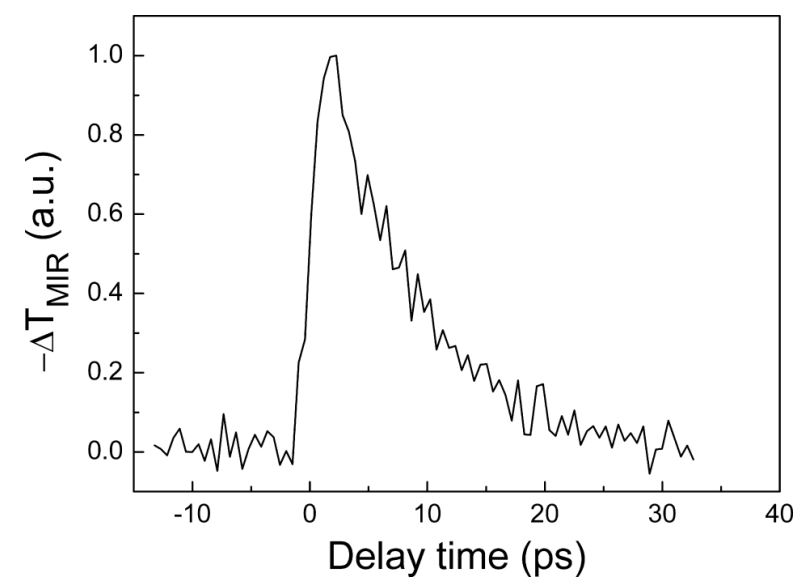

Fig. 1. Time dependence of the mid-IR differential transmission signal for the annealed LTG sample grown at $270{ }^{\circ} \mathrm{C}$.

crystal. The mid-IR pulse was selected from signal and idler pulses by dichroic mirror coated on $\mathrm{ZnSe}$. The probe pulse energy was less than $1 \mu \mathrm{J}$. The pump pulse energy was changed from 4 to $48 \mu \mathrm{J}$; the intensity of the probe beam was measured by a pyroelectric detector and a lock-in amplifier. The presented in Figs. 1 and 5 curves were measured with $4 \mu \mathrm{J}$ pump power.

\section{Experimental results}

\subsection{Low-temperature-grown GaAs}

Carrier density dynamics in LTG GaAs was documented by investigating photocurrent transients [9], pump-and-probe reflectance [10] and transmittance [11], time-resolved photoluminescence [12], and optical pump - THz probe experiments [13]. All these experiments are predominantly sensitive to the presence of electrons in the sample, therefore electron dynamics in LTG GaAs is by far better investigated and understood than hole dynamics. Electron trapping time in LTG GaAs is shown to increase with the increase in both the growth and the annealing temperature and is mainly determined by the presence of deep As-antisite donor levels [14].

The only direct way to measure hole trapping time in GaAs is to use the optical pump - mid-IR probe experiment [7]. Figure 1 shows the results of such a measurement made on a LTG GaAs sample grown at $270{ }^{\circ} \mathrm{C}$ and annealed at $600{ }^{\circ} \mathrm{C}$ temperature. As can be seen from the figure, pump-induced mid-IR transmittance (and the nonequilibrium hole density) decays with a characteristic time of $\sim 10 \mathrm{ps}$, which is much slower than the electron trapping time in this material. It has been shown in Ref. [7] that the hole trapping times in

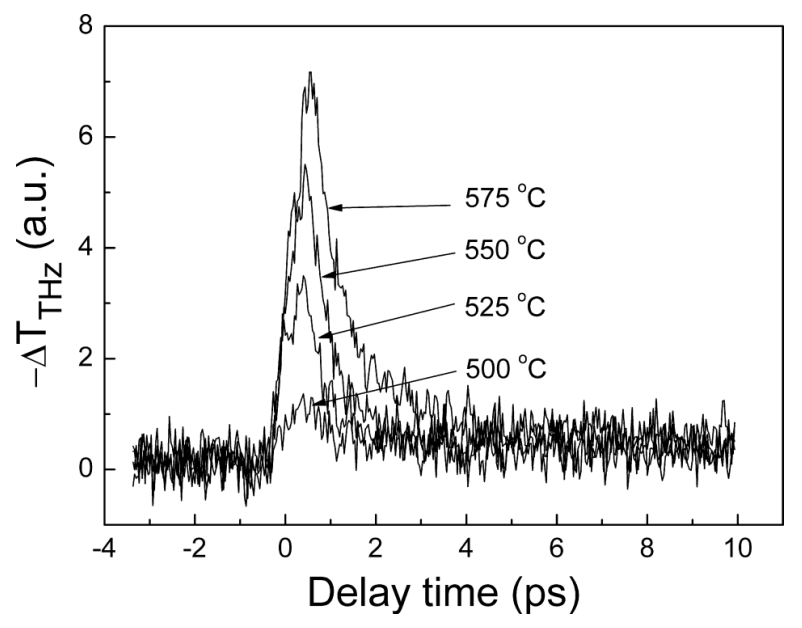

Fig. 2. Time dependence of the $\mathrm{THz}$ differential transmission signal for the LTG GaAs sample grown at $235{ }^{\circ} \mathrm{C}$ and annealed at different temperatures.

LTG GaAs correlate with the neutral As-antisite density, indicating that these defects are the main hole capture centres in LTG GaAs layers.

Figure 2 shows the results of optical pump $-\mathrm{THz}$ probe measurements performed on LTG GaAs grown at $235^{\circ} \mathrm{C}$ and annealed at different temperatures. Characteristic decay times of $\mathrm{THz}$ transmission measured on the layers annealed at the temperatures from 500 to $575{ }^{\circ} \mathrm{C}$ are similar $(\sim 0.75 \mathrm{ps})$ and most probably determined by the temporal resolution of the experiment set by the $\mathrm{THz}$ pulse duration. Higher annealing temperature leads to an increase of the $\mathrm{THz}$ transmittance modulation depth, which could be explained by the increase of the photoexcited electron mobility with more efficient anneal of the As-antisite defects.

Results of a similar investigation of LTG GaAs layer grown at a higher temperature $\left(270{ }^{\circ} \mathrm{C}\right)$ are presented in Fig. 3. In this case, the decay times of the induced $\mathrm{THz}$ absorption, which we interpret as the electron trapping times in the layers, are significantly longer. Moreover, in samples annealed at $700{ }^{\circ} \mathrm{C}$ and higher temperatures the decay of the signal is no longer characterized by a single exponential and the slowly decaying tails appear. Such a tail could be explained by the saturation of the electron traps - ionized As-antisites - which are emptied when holes are trapped at the neutral As-antisites. As it is already indicated, this process in LTG GaAs is known to be much slower than the electron trapping. However, the photoexcited carrier concentration in our experiments was lower than $4 \cdot 10^{16} \mathrm{~cm}^{-3}$, thus the tails can hardly be explained by the saturation of the traps, which at these anneal temperatures have at least twice the density (as estimated from the electron times in the initial part of the decay by using an electron 


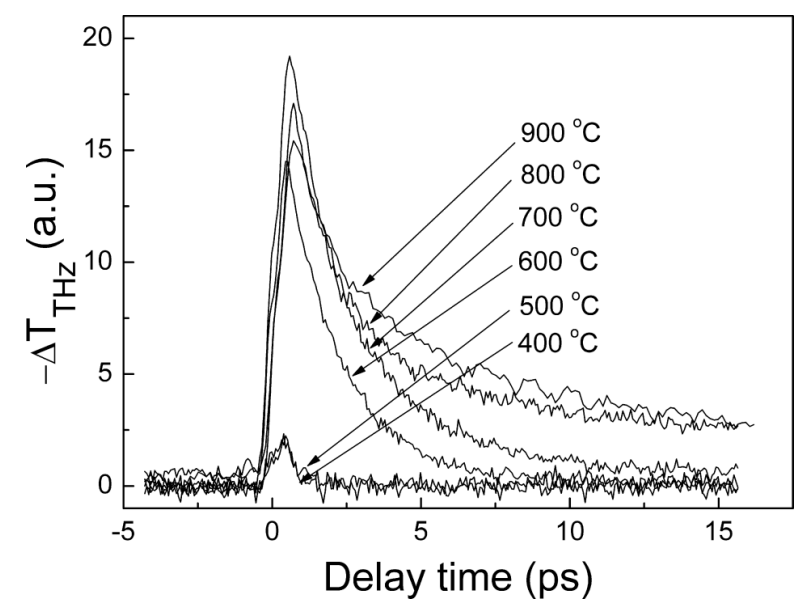

Fig. 3. Time dependence of the $\mathrm{THz}$ differential transmission signal for the LTG GaAs sample grown at $270{ }^{\circ} \mathrm{C}$ and annealed at different temperatures.

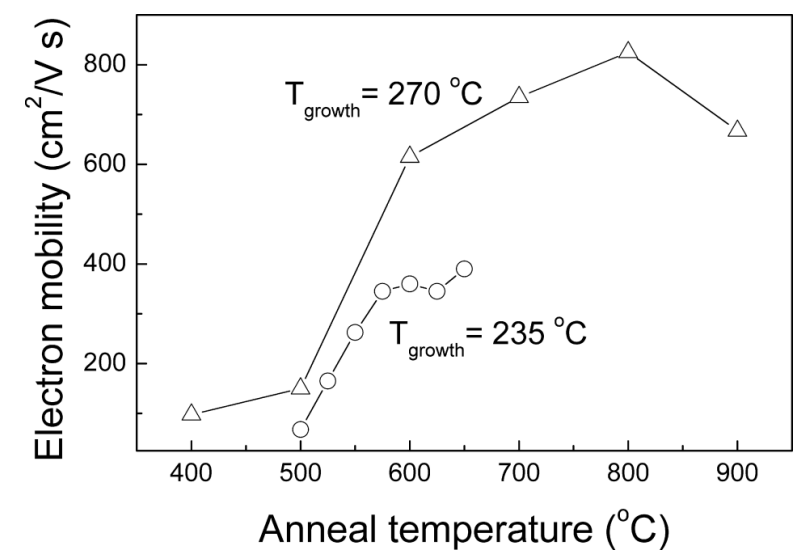

Fig. 4. Electron mobility of the LTG GaAs samples as a function of annealing temperature.

capture cross-section of $1.1 \cdot 10^{-13} \mathrm{~cm}^{2}$ [14]). Therefore, the observed long decay tails in LTG GaAs samples annealed at higher temperatures is caused by another mechanism, most probably by the effect of large As-precipitates that are formed at those temperatures.

The modulation of $\mathrm{THz}$ transmittance by the optical pump pulse can be exploited also for an independent determination of the electron mobility in the material. According to the Drude theory, the intensity absorption coefficient of the $\mathrm{THz}$ waves will be proportional to the electron mobility; therefore even in the material with sub-picosecond carrier lifetime this mobility can be evaluated by comparing the $\mathrm{THz}$ transmittance change induced by the optically excited carriers with the effect of the same optical pulse on the transmittance of a reference crystal with known electron transport parameters. In this work, Cr-doped semiinsulating GaAs wafers with the electron mobility of $3000 \mathrm{~cm}^{2} /(\mathrm{V} \cdot \mathrm{s})$ were used as a reference. Figure 4

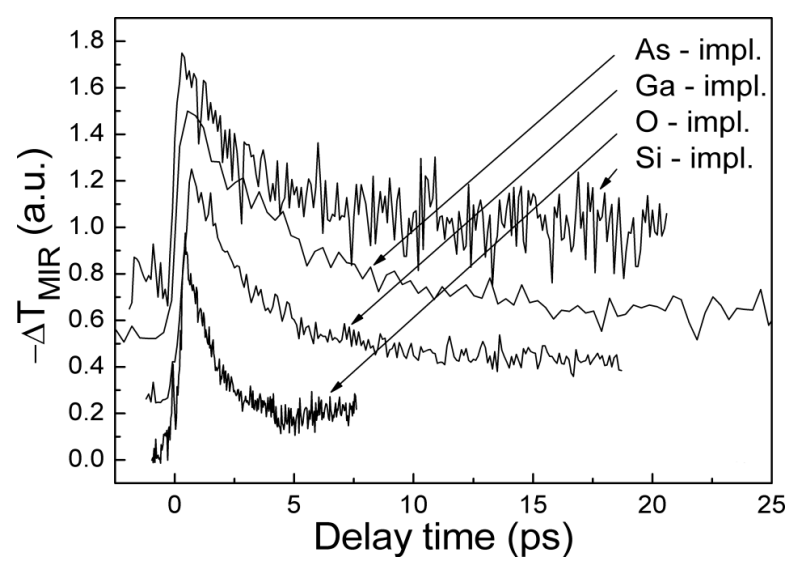

Fig. 5. Time dependence of the mid-IR differential transmission signal for the implanted GaAs samples. The implantation dose was $10^{16} \mathrm{~cm}^{-2}$. The curves are offset from the origin for clarity.

shows electron mobilities in LTG GaAs layers grown at two different temperatures as a function of annealing temperature. Mobilities in annealed LTG GaAs grown at a higher temperature were found to be of the range of $500-800 \mathrm{~cm}^{2} /(\mathrm{V} \cdot \mathrm{s})$, which is lower than the data obtained by photo-Hall measurements [14] but larger than the data estimated from photocurrent magnitude [1]. Moreover, the electron mobility starts to decrease at the highest annealing temperatures and that could be also interpreted as an indication of the appearance of As-precipitates acting as additional electron scattering centres in LTG GaAs.

\subsection{Ion-implanted GaAs}

Results of optical pump - mid-IR measurements of the hole relaxation in GaAs crystals implanted with four different ion species at $10^{16} \mathrm{~cm}^{-2}$ implantation dose and annealed at $600{ }^{\circ} \mathrm{C}$ for $20 \mathrm{~min}$ are shown in Fig. 5. As it can be seen from this figure, the hole trapping times in $\mathrm{As}, \mathrm{Ga}, \mathrm{Si}$, and $\mathrm{O}$ implanted samples are of a similar order of magnitude (2-5 ps). At smaller implantation dose $\left(10^{15} \mathrm{~cm}^{-2}\right)$ the hole trapping times in $\mathrm{As}, \mathrm{Ga}, \mathrm{Si}$, and $\mathrm{O}$ implanted samples were about 10 ps. This can be understood if we suppose that the main effect leading to the shortening of the carrier lifetimes in all cases is the nonstoichiometric disturbance in GaAs induced by the high energy ions [15]. During the implantation, lighter $\mathrm{Ga}$ ion recoil further in the bulk of the crystal than heavier As ions, thus a layer with excess As will appear closer to the surface of the implanted GaAs and a layer with excess gallium will appear deeper in the bulk of the crystal. As in the case of LTG GaAs, excess As can lead to the formation of As-related defects that will act as the traps. 


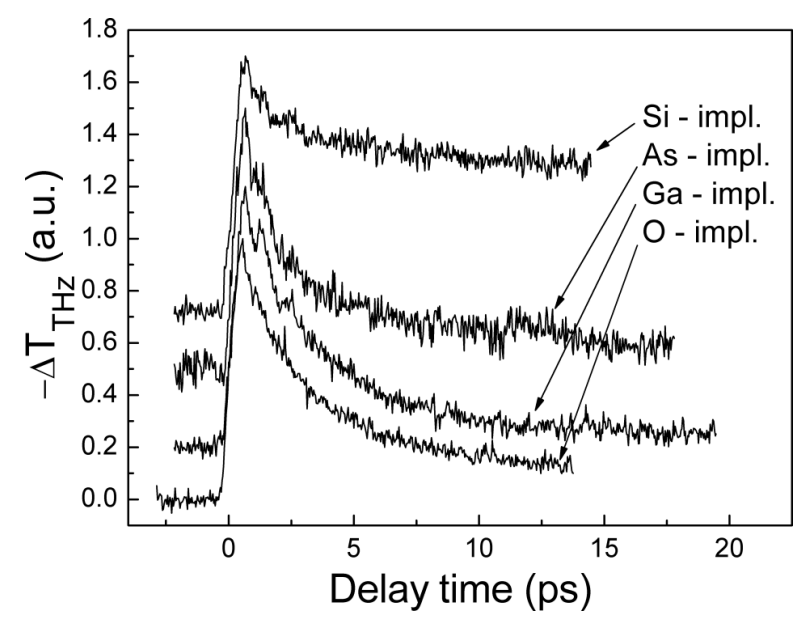

(a)

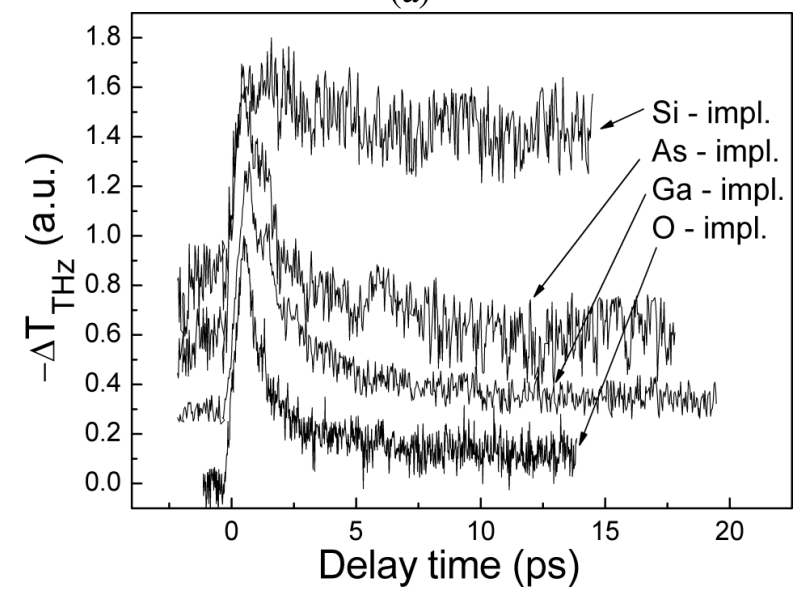

(b)

Fig. 6. Time dependence of the $\mathrm{THz}$ differential transmission signal for the implanted GaAs samples. The implantation dose was (a) $10^{15} \mathrm{~cm}^{-2}$ and (b) $10^{16} \mathrm{~cm}^{-2}$. The curves are offset from the origin for clarity.

The shortest hole trapping times are observed in O-implanted samples when the implantation dose was equal to $1 \cdot 10^{16} \mathrm{~cm}^{-2}$. Moreover, an unambiguous linear relationship between the inverse hole trapping time and the O-implantation dose is evident in this case. These observations allow us to claim that oxygen is creating efficient hole trapping centres in GaAs. It is known that $\mathrm{O}$ creates a whole spectrum of deep levels in the bandgap of GaAs that are equally effective by compensating both $n$ - and $p$-type shallow impurities [16]. Our results show that some of these levels can act as efficient hole traps in GaAs.

The photoexcited electron density relaxation in ionimplanted GaAs, as measured by the optical pump $\mathrm{THz}$ probe technique at two different implantation doses and annealed at $600{ }^{\circ} \mathrm{C}$, are shown in Fig. 6 . Three experimental traces corresponding to As, Ga, and O-implanted samples are very similar showing that

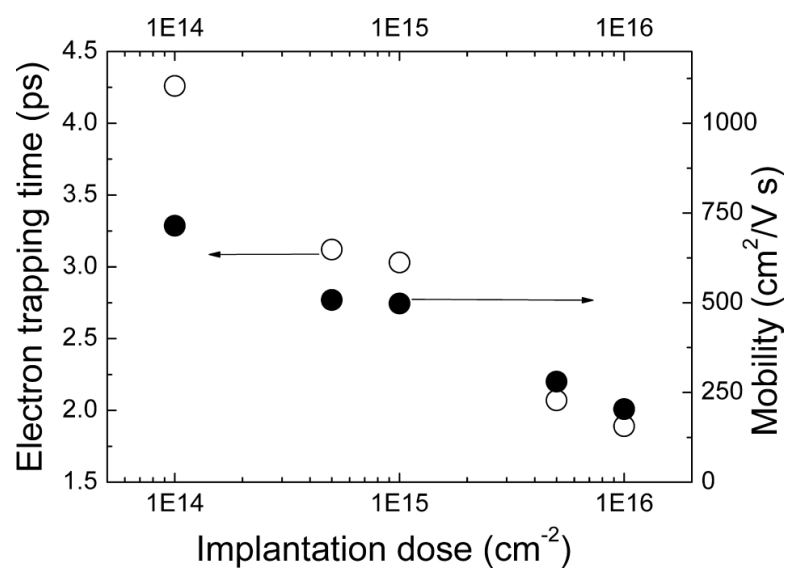

Fig. 7. Electron mobility and trapping time of the Ga-implanted $\mathrm{GaAs}$ as a function of implantation dose.

non-equilibrium electrons are trapped on the picosecond time scale. Only in the Si-implanted samples the pump-induced change in $\mathrm{THz}$ transmittance decays much slower. This result contradicts to the conclusion made in Ref. [3], where it has been supposed that the electron trapping in GaAs implanted by those four ion species is equally fast. However, time-resolved photoluminescence measurement, which was employed in Ref. [3], is sensitive to the changes in the product of electron and hole densities and, therefore, does not allow to distinguish the carriers of which type are trapped first. We already know from the experiments described above, that the holes in Si-implanted GaAs are also characterized by picosecond trapping times. It is possible that the slower trapping of electrons is caused by the activation of the implanted $\mathrm{Si}$ ion to form $n$-type material in GaAs.

Electron trapping time and electron mobility determined using optical pump - THz probe measurement decrease while increasing implantation dose (Fig. 7).

\section{Comparison of different nonstoichiometric GaAs materials}

After measuring electron and hole trapping characteristics in both LTG and ion-implanted GaAs, a closer comparison of these two types of nonstoichiometric materials is possible. It would be reasonable to perform such comparison from the point of view of applications of these materials in THz optoelectronic devices. Such a comparison is provided in Fig. 8, where electron and hole trapping times in GaAs samples obtained by different technologies are presented.

Laser activated $\mathrm{THz}$ emitters and detectors are, essentially, photoconductive components integrated with wide band antennae and therefore, Si-implanted GaAs 


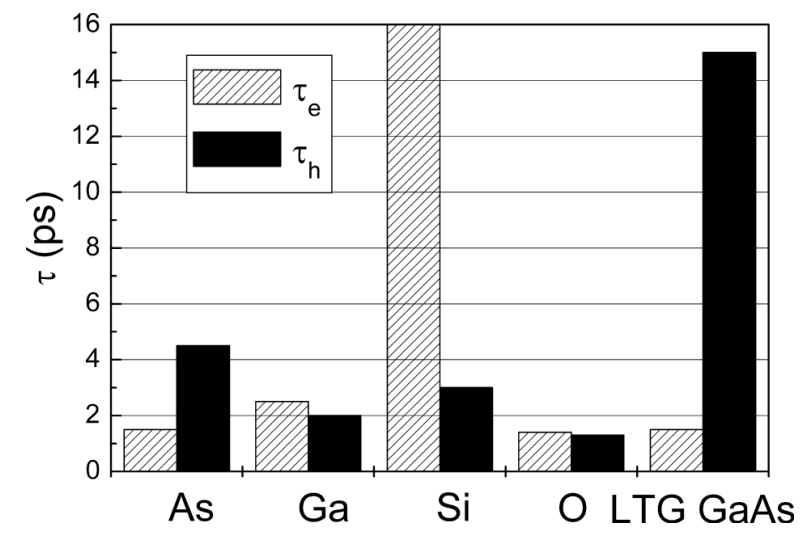

Fig. 8. Electron and hole trapping times of the LTG GaAs $\left(T_{\text {growth }}=270{ }^{\circ} \mathrm{C}\right)$ and $\mathrm{GaAs}$ implanted with As, Ge, Si, and O ions (implantation dose was $10^{16} \mathrm{~cm}^{-2}$ ).

can be excluded from the consideration because of its large conductivity [3] and rather long electron trapping times. On the other hand, As, Ga, and O-implanted GaAs are highly resistive after thermal annealing and can be used as substrates for $\mathrm{THz}$ photoconductors. Electron trapping times in these crystals are quite short; however, they approach 1 ps only when the ion implantation dose is very large $\left(\geq 10^{16} \mathrm{~cm}^{-2}\right)$. For such large doses, the electron mobility in the material becomes small, thus a wide band of the devices is achievable only at the cost of their sensitivity and efficiency. From this point of view the use of LTG GaAs is preferable, because in this material the electron mobility remains at a satisfactory level even when their trapping times are much shorter than 1 ps. From all ion-implanted materials investigated in this study only O-implanted GaAs can provide the electron trapping time and mobility combination comparable with the set of corresponding LTG GaAs parameters.

However, ion-implanted GaAs crystals are, in general, characterized by considerably shorter hole trapping times than LTG GaAs. Short hole trapping times are essential for devices such as $\mathrm{cw} \mathrm{THz}$ emitters based on the optical mixing effect [16]. Also in this case, the shortest hole trapping times were obtained for O-implanted samples. It should be pointed out that oxygen ions are the lightest of all ion species used in this study and therefore the damage induced by O-implantation should be the smallest for the same implantation dose. Therefore, the ultrafast recombination properties of O-implanted GaAs samples cannot be explained by the defects created during the implantation. Most probably oxygen related defects act as effective non-equilibrium carrier recombination centres in this case.

\section{Conclusions}

In conclusion, we have investigated electron and hole trapping times and electron mobilities in LTG GaAs and GaAs crystals implanted by four different ion species. Two-colour pump-and-probe techniques have been used in these experiments. Nonequilibrium electrons and holes were excited by illuminating the samples with $800 \mathrm{~nm}$ wavelength femtosecond laser pulses, whereas the dynamics of their populations was monitored at considerably longer wavelengths thus avoiding any interference related experimental artifacts. Recombination parameters of the investigated materials were compared in relation to the applications of these materials in $\mathrm{THz}$ radiation devices. It has been concluded that LTG GaAs is preferable material for $\mathrm{THz}$ applications for its shorter electron trapping times and electron mobilities. However, the hole trapping time in ion-implanted material is shorter than in LTG GaAs, making it a suitable candidate for devices working in cw-mode such as optical mixers. The shortest carrier trapping times and the largest electron mobility was found for O-implanted material.

\section{Acknowledgements}

This work was, in part, supported by the NATO "Science for Peace" grant SfP-977978 "Terahertz radiation systems". The research at the Australian National University was supported by the Australian Research Council. The authors acknowledge Vilnius University Laser Research Centre for providing possibility to perform mid-IR probe experiments.

\section{References}

[1] D.D. Nolte, J. Appl. Phys. 85, 6259 (1999).

[2] A. Krotkus, S. Marcinkevicius, J. Jasinski, M. Kaminska, H.H. Tan, and C. Jagadish, Appl. Phys. Lett. 66, 3304 (1995).

[3] C. Jagadish, H.H. Tan, A. Krotkus, S. Marcinkevicius, K.P. Korona, and M. Kaminska, Appl. Phys. Lett. 68, 2225 (1996).

[4] M. Lederer, B. Luther-Davies, H.H. Tan, and C. Jagadish, IEEE J. Quantum Electron. 34, 2150 (1998).

[5] T.A. Liu, M. Tani, and C.L. Pan, J. Appl. Phys. 93, 2996 (2003).

[6] J. Lloyd-Hughes, E. Castro-Camus, M.D. Fraser, C. Jagadish, and M.B. Johnston, Phys. Rev. B 70, 235330 (2004). 
[7] R. Adomavicius, A. Krotkus, K. Bertulis, V. Sirutkaitis, R. Butkus, and A. Piskarskas, Appl. Phys. Lett. 83, 5304 (2003).

[8] J.S. Blakemore, J. Appl. Phys. 53, R123 (1982).

[9] F.W. Smith, H.Q. Lee, V. Diadiuk, M.A. Holis, A.R. Calawa, S. Gupta, M. Frankel, D.R. Dykaar, G.A. Mourou, and T.Y. Tsiang, Appl. Phys. Lett. 54, 890 (1989).

[10] J.F. Roux, J.L. Coutaz, and A. Krotkus, Appl. Phys. Lett. 74, 2462 (1999).

[11] U. Siegner, R. Fluck, G. Zhang, and U. Keller, Appl. Phys. Lett. 69, 2566 (1996).

[12] A. Krotkus, R. Viselga, K. Bertulis, V. Jasutis,
S. Marcinkevicius, and U. Olin, Appl. Phys. Lett. 66, 1939 (1995).

[13] S.S. Prabhu, S.E. Ralph, M.R. Melloch, and E.S. Harmon, Appl. Phys. Lett. 70, 2419 (1997).

[14] A. Krotkus, K. Bertulis, M. Kaminska, K. Korona, A. Wolos, J. Siegert, S. Marcinkevicius, J-F. Roux, and J.-L. Coutaz, IEEE Proc.: Optoelectron. 149, 111 (2002).

[15] Y. Zhang, E-J. Ding, and T. Zhang, Nucl. Instrum. Methods Phys. Res. B 152, 307 (1999).

[16] E.R. Brown, K.A. Macintosh, K.B. Nichols, and C.L. Dennis, Appl. Phys. Lett. 66, 285 (1995).

\title{
KRŪVININKŲ REKOMBINACIJOS SAVYBĖS ŽEMOJE TEMPERATŪROJE IŠAUGINTAME IR JONAIS IMPLANTUOTAME GaAs
}

\author{
A. Geižutis ${ }^{\text {a }}$, R. Adomavičius ${ }^{\text {a }}$, A. Urbanowicz ${ }^{\text {a }}$, K. Bertulis ${ }^{\text {a }}$, A. Krotkus ${ }^{\text {a }}$, H.H. Tan ${ }^{\text {b }}$, C. Jagadish ${ }^{\text {b }}$ \\ a Puslaidininkiu fizikos institutas, Vilnius, Lietuva \\ ${ }^{\mathrm{b}}$ Australijos nacionalinis universitetas, Kanbera, Australija
}

\begin{abstract}
Santrauka
Išmatavome elektronų ir skyliu pagavimo trukmes bei elektronų judrị žemoje temperatūroje augintame GaAs (ŽT-GaAs) bei GaAs kristaluose, implantuotuose $\mathrm{As}, \mathrm{Ga}, \mathrm{Si}, \mathrm{O}$ jonais. Eksperimentuose buvo naudojamos optinio žadinimo - terahercino zondavimo ir optinio žadinimo - infraraudonuju spindulių zondavimo metodikos. Tirtų medžiagų rekombinacijos parametrai buvo ịvertinti, atsižvelgiant $i$ šių medžiagų pritaikymą THz emiteriuose.
\end{abstract}

Darome išvadą, kad ŽT-GaAs dèl trumpesnių elektronų pagavimo trukmių ir didesnio judrio labiausiai tinka THz pritaikymams. Kita vertus, jonais implantuotų medžiagų skyliu pagavimo trukmès trumpesnès negu ŽT-GaAs. Ši savybè leistų naudoti implantuotas medžiagas nuostoviosios veikos prietaisuose, pavyzdžiui, THz optiniuose maišytuvuose. Iš visų implantuotų medžiagu trumpiausiomis krūvininkų pagavimo trukmėmis ir didžiausiu elektronų judriu pasižymejjo deguonimi implantuotas GaAs. 